UDC 336.132.2

JEL: G01, G15, G17, G23, O16

\title{
EVALUATION OF DERIVATIVES IMPACT TO EARLY SYSTEMIC RISK OF EURO AREA
}

Introduction. Evaluation of systemic risk is very complicated, as it is difficult to accurately predict the extent of the links between various institutions, and the possible spread and scale of the country's systemic risk. In addition, the country's systemic crisis is affected by many factors, many elements of the financial system. Financial derivatives are one of many elements of financial system, and the market of financial derivatives is huge compared to other financial instruments. The impact of financial derivatives to economies of various countries has been widely studied, however, the research on their impact to countries' early systemic risk remains underresearched. For this reason, assessment of the impact of derivative financial instruments on the early systemic risk is very relevant.

Aim and tasks. The purpose of the article is to assess the impact of financial derivatives on the country's early systemic risk in the Euro area region.

Results. It is shown that correlation fluctuates between weakstrong level, when analyzing relationship between various factors of financial derivatives and early systemic risk in the Euro area. Results of linear regression analysis prove that the group of financial derivatives independent variables (interconnection, size, liquidity, complexity, stability, leverage) can be used to reliably estimate the dependent variable (early systemic risk). Logistic regression analysis also provides similar results to the linear regression analysis. Additionally, it is shown, that logistic regression is more suitable to analyze impact on early systemic risk. Analysis of impact of individual financial derivatives factors to early systemic risk demonstrate, that three financial derivatives factors - size, complexity, and leverage - may be the best predictors of an impending systemic crisis. Among these factors, the size factor has the largest impact on early systemic risk of the Euro area, and complexity factor shows improved statistical parameters, which indicates, that this parameter is more suitable to be used in early warning system models.

Conclusions. The use of financial derivatives has strong impact on early systemic risk in the Euro area. The size factor of financial derivatives indicates the highest probability of an impending systemic crisis. Nevertheless, complexity factor of financial derivatives is the only statistically significant factor, that has an impact on early systemic risk. The results suggest that the inclusion of these factors in the systemic risk assessment models, which are developed by researchers, could increase the accuracy of the models. It is noted, that country's systemic risk may not necessarily arise in financial derivatives, because there are many different financial products in the financial system. As a result, other financial instruments could also be the subject to further research by scientists. The inclusion of factors of various financial instruments could help to better identify the risks of impeding systemic crisis in systemic risk assessment models.

Key words: financial derivatives, systemic risk, early warning systems, financial instruments.

(C) Economics. Ecology. Socium, 2020

CC BY-NC 4.0 license 


\section{УДК 336.132.2 \\ JEL: G01, G15, G17, G23, O16}

\section{Ріма Житісне}

Професор, факультет економіки та бізнесу,

Університет Миколаса Ромеріса,

Вільнюс, Литва

E-mail: rizit3@mruni.eu

orcid.org/0000-0002-0954-7251

\section{Валдас Григоніс}

Аспірант спеціальності

«Економічні науки», факультет

економіки та бізнесу,

Університет Миколаса Ромеріса,

Вільнюс, Литва

E-mail: valgrigonis@mruni.eu

orcid.org/0000-0002-6359-9589

\section{Павло Бурак}

Аспірант спеціальності

«Економічні науки», факультет економіки та бізнесу,

Університет Миколаса Ромеріса, Вільнюс, Литва

E-mail: pavel.v.burak@gmail.com orcid.org/ 0000-0001-5689-4355

Отримано: Січень, 2020

Прийнято: Беезень, 2020

DOI:10.31520/2616-7107/2020.4.1-7

(C) Економіка. Екологія. Соціум, 2020 CC BY-NC 4.0 ліцензія

\section{ОЦІККА ВПЛИВУ ПОХІДНИХ НА РАННІЙ СИСТЕМНИЙ РИЗИК ЄВРОЗОНИ}

Вступ. Оцінка ринкового ризику є складним процесом, так як достатньо важко проаналізувати зв'язки між різними установами, а також можливу ступінь розповсюдження та масштаб національного ринкового ризику. Національна системна криза відбувається під впливом багатьох чинників та елементів фінансової системи. Похідні фінансові інструменти $\epsilon$ одним з багатьох елементів фінансової системи, а ринок цих інструментів значно перевищує об'єми інших фінансових інструментів. Вплив похідних фінансових інструментів на економіку різних країн вже було широко досліджено, однак тема їх впливу на ранній ринковий ризик країн залишається нерозкритою. Таким чином, оцінка впливу похідних фінансових інструментів на ринковий ризик $є$ важливою.

Мета та завдання. Метою статті $€$ оцінка впливу похідних фінансових інструментів на ранній ринковий ризик країн Єврозони.

Результати. При аналізі різних факторів похідних фінансових інструментів та раннього ринкового ризику у країнах Єврозони визначнено, що їх взаємозв'язок коливається від сильного до незначного. Результати лінійно-регресивного аналізу демонструють, що незалежні змінні, які входять до похідних фінансових інструментів (взаємозв'язок, розмір, ліквідність, складність, стабільність, співвідношення різних видів капіталу) можуть використовуватися для достовірної оцінки залежної змінної. Логістичний регресивний аналіз $\epsilon$ більш прийнятним для аналізу впливу на ранній ринковий ризик. Аналіз впливу окремих факторів різних похідних фінансових інструментів на ранній ринковий ризик також показав, що три фактори похідних фінансових інструментів (розмір, складність та співвідношення різних видів капіталу) $\epsilon$ найкращими маркерами близької системної кризи. Серед вищезазначених факторів найбільший вплив на ранній ринковий ризик країн Єврозони має фактор розміру, в той час як фактор складності демонструє покращені статистичні показники, за якими i було визначено, що даний фактор $\epsilon$ більш прийнятним для використання у моделях системи попереднього попередження.

Висновок. Використання похідних фінансових інструментів має значний вплив на ранній ринковий ризик країн Єврозони. Фактор розміру похідних фінансових інструментів визначає найбільшу вірогідність близької системної кризи. Єдиним статистично значущим фактором, що впливає на ранній ринковий ризик, є фактор складності похідних фінансових інструментів. Результати дослідження демонструють, що включення вищезазначених факторів до моделей оцінювання ринкового ризику може підвищити точність цих моделей. Ринковий ризик не обов'язково виникає 3 похідних фінансових інструментів, так як фінансова система складається із різних фінансових продуктів. Інші фінансові інструменти також можуть стати предметом подальших досліджень. Аналіз додаткових факторів фінансових інструментів може допомогти при визначенні ризиків близької системної кризи у моделях оцінювання ринкового ризику.

Ключові слова: фінансові похідні, системний ризик, системи попереднього попередження, фінансові інструменти. 
Introduction. While the benefits of financial derivatives to the economy and to the financial system itself are recognised by researchers, they also pose risks. This is evidenced by the collapses of Barings PLC, Metallgesellschaft, Long-Term Capital Management, Bear Stearns, Lehman Brothers and financial difficulties of other companies (JPMorgan Chase \& Co., Société Générale, American International Group Inc., UBS et al.), caused by the trade in financial derivatives. However, the risk posed by derivative financial instruments to individual companies is just one area of the risky nature of these financial instruments. One of the most significant risks is the impact of financial derivatives on the country's systemic risk. The global financial crisis of 2008 was one of the most prominent examples of how financial derivatives can negatively affect the financial system.

The country's systemic risk has become a fairly widely discussed topic since the global financial crisis of 2008. Until 2008 researchers have been paying relatively little attention to this risk, but there were attempts to develop country's systemic risk models and to emphasise the risk posed by country's systemic risk. After the crisis in the global financial system, the focus of scientists to the country's systemic risk has become quite relevant, in particular, the number of scientific articles and research, attempts to model and assess the country's systemic risk has grown. The interest of researchers in this field continues to grow, looking for new ways to assess the country's systemic risk, to predict it, to develop a more accurate model of the country's systemic risk and prevent possible future systemic crises in the country. There is a growing interest among researchers in the development of an Early warning system that helps to assess the relationship between an independent variable for the current period and a dependent variable for a future period. Such models can be used to as early warning of the level of the country's systemic risk.

It has been noted that evaluating systemic risk is very complicated task, as it is difficult to accurately predict the extent of the links between various institutions, and the possible spread and scale of the country's systemic risk.
In addition, the country's systemic crisis is affected by many factors, a big number of elements of the financial system, including derivative financial instruments. Financial derivatives are one of many elements of financial system, and the market of financial derivatives is huge compared to other financial instruments. The impact of financial derivatives to economies of various countries has been widely studied, however, the research on their impact to countries' early systemic risk remains under-researched. For this reason, assessment of the impact of derivative financial instruments on the country's early systemic risk is very relevant.

Analysis of recent researches and publications. Many scientists, such as Ronald MacDonald et al. [1], Elena Duggar et al. [2], Giovanni Caggiano et al. [3], Abino D. J. et al. [4], Smaranda Cimpoeru [5], Powell S. G. et al. [6], Rodríguez-Moreno M. et al. [7], have analysed the early warning system models of the country's systemic risk. However, scientific research lacks a more detailed analysis of the impact of financial derivatives on the country's early systemic risk, despite the fact that the derivative financial instruments market is significantly large, much larger than the equities, bonds or other securities financial markets. Contributing to the achievement of researchers in early warning system models, this study is conducted to assess the impact of financial derivatives on the country's early systemic risk.

The aim of the article. The aim of this study is to assess the impact of financial derivatives on the country's early systemic risk in the Euro area region.

Methodology. The article sample consists of the data on financial derivatives, other financial products and GDP of the Euro area region. The chosen research period is 20002018, taking into account the availability of data. The frequency of half-yearly data was used in the study as the choice was affected by the periodicity of publication of data on financial derivatives.

A logistic model was used to evaluate the results, allowing to estimate the effect of individual factors on the dependent variable. The model is universal, enabling the country's systemic risk to be assessed as a probability. 
Independent variables were selected according to the research of Mačerinskienè I. et al. [8], and estimation of independent variables was performed according to the methods defined by Mačerinskiene I. et al. [9]: the HHI index was used to estimate the size factor of derivatives, the ratio of turnover and the total value of derivatives was used to estimate the liquidity factor, the indicator of the derivatives calculation complexity was used for complexity factor, the rolling standard deviation was used for the assessment of the stability factor, the ratio of the nominal derivatives value to GDP for the leverage factor and the rolling correlation indicator for the interconnection factor.

The authors assigned the value " 0 " for the dependent binary variable in cases where there is no systemic risk, otherwise the dependent variable had a value of "1". The country's systemic risk period was determined on the basis of the research of the Luc Laeven et al. [10], who found that the systemic crisis began in the second half of 2007, and ended in 20112013 in most European countries. In addition, the Composite Indicator of Systemic Stress (CISS) published by the ECB (see the chart in Figure 1) shows that the CISS index was very high between the end of the second half of 2007 and the end of 2013, - well above historical lows.

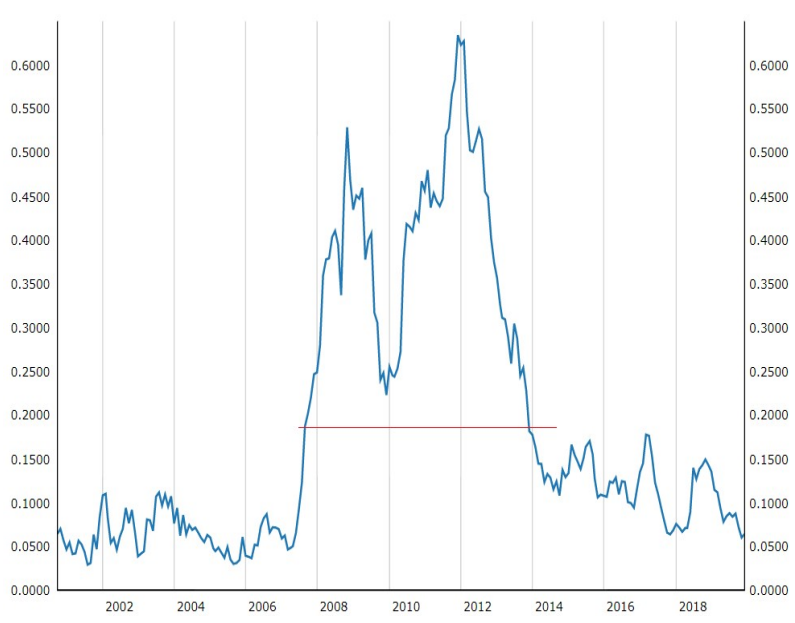

Figure 1. Systemic stress composite indicator of Euro area 2000- 2018.

Source: created by the author based on European Central Bank data [14].
Taking into account the research of scholars, a composite indicator of systemic stress, the authors chose the period from the second half of 2007 to the end of 2013 during the systemic crisis. As the aim of the article is to assess the impact of financial derivatives on the country's early systemic risk, the value of systemic crises for dependent variable was lagged by half year. This period was chosen because in practice the central bank can intervene in the market and control it at least to some extent within 6 months (Lo Duca M. et al. [11]). Moreover, various researchers also use a 6 - month period in their studies [3-7]. Therefore, the value of "1" was assigned to systemic risk in the period from the beginning of 2007 to the first half of 2013, and the value of " 0 " in other periods.

Statistical calculations were performed using the Stata program. Calculations were carried out using statistical research methods. The Pseudo R2 indicator, the "Prob> chi2" criterion, the "goodness of fit" and successful classification tests were used to assess statistical significance. Additionally, correlation between the factors was checked. Heteroskedasticity (Breusch-Pagan) test, multicollinearity (VIF index) test was performed for the selection of factors.

Results. The analysis of the relationship between financial derivatives factors and early systemic risk in the Euro area showed a weakstrong ${ }^{[12]}$ linear correlation (see Table 1). The correlation of the interconnection factor was found to be weak and equal to 0.29 . The p-value criterion for this factor is 0.09 and below the significance level $\alpha=0.05$, therefore, the correlation of this factor is statistically insignificant. The size factor correlation was calculated to be strong, equal to 0.70 , and the strongest among all factors, while the p-value criterion ("0") indicates that the calculated correlation is statistically significant. The correlation of the liquidity factor is weak at 0.22 . This correlation is the weakest among all factors and the p-value criterion is 0.22 and above the significance level $\alpha=0.05$, which leads to the conclusion that this factor is statistically insignificant. The complexity factor correlation was calculated to be strong at -0.69 , and the p-value criterion ("0") indicates that the calculated correlation is statistically significant. 
The correlation of the stability factor was found to be weak at 0.39 . The $\mathrm{p}$-value criterion for this factor is 0.02 , therefore, the correlation of this factor is statistically significant. The leverage factor correlation was calculated to be average, equal to 0.56 , and the p-value criterion ("0") indicates that the calculated correlation is statistically significant.

Table 1. Pairwise correlation between systemic risk and financial derivatives factors of Euro area

\begin{tabular}{|l|l|l|l|l|l|l|}
\hline Parameter & $\begin{array}{l}\text { Interconnection } \\
\text { factor }\end{array}$ & Size factor & $\begin{array}{l}\text { Liquidity } \\
\text { factor }\end{array}$ & $\begin{array}{l}\text { Complexity } \\
\text { factor }\end{array}$ & $\begin{array}{l}\text { Stability } \\
\text { factor }\end{array}$ & $\begin{array}{l}\text { Leverage } \\
\text { factor }\end{array}$ \\
\hline Correlation & 0.2974 & 0.6998 & 0.2182 & -0.6929 & 0.3891 & 0.5591 \\
\hline $\begin{array}{l}\text { P-value } \\
\text { criterion of } \\
\text { correlation }\end{array}$ & 0.0876 & 0.0000 & 0.2150 & 0.0000 & 0.0229 & 0.0006 \\
\hline
\end{tabular}

Source: created by the authors

It should be noted, that statistically lowest p-value criterion is for the size, complexity, and leverage factors. Moreover, the pairwise correlation between these factors and early systemic risk of the Euro area's is strongest. Comparing results to the base model [13], where research was carried out between financial derivatives factors and present (non-early) systemic risk of Euro area, the correlation increased with respect to liquidity and complexity factors, while it decreased with respect to other factors. In addition, two statistically insignificant correlation coefficients (interconnection and liquidity) emerged in the early systemic risk model. Among the remaining four factors, the correlation decreased the most and the p-value criterion increased the most in respect of the stability factor, suggesting poorer suitability of this factor in the early systemic risk model, although still statistically significant. To sum up, it is clear that there is a link between financial derivatives and the early systemic risk of the Euro area, and the estimated impact is strong and statistically significant.

During the next step, a linear regression analysis was performed for all factors. Based on the result of the indicator "Prob $>F$ ", it can be seen that the calculated value $(0.0001)$ is lower than the significance level $(0.05)$, therefore, it can be assumed that a group of independent variables (interconnection, size, liquidity, complexity, stability, leverage) can be used to reliably estimate the dependent variable (early systemic risk).
Such results, in turn, suggest that the model is suitable for assessing the impact of financial derivatives on early systemic risk. It should be noted that the individual statistical significance of each independent variable is assessed, using pvalue criterion of each independent variable. Although the group of independent variables can reliably estimate impact to early systemic risk, however, some individual variables are statistically insignificant.

The calculated estimates of the dependent variable of the linear regression are presented in Figure 2. The presented results clearly demonstrate that the linear regression model is not suitable for the assessment of systemic risk, which is described as probability [13]. In the study, the value of dependent variable goes beyond the boundaries of " 0 " and " 1 " when a linear model is used for analysis, and such boundary violations are more common in the case of the early systemic risk model. However, logistic regression is suitable, since the values of dependent variable never breach the boundaries of " 0 " and " 1 ".

Based on the results of the correlation and linear regression analysis, a logistic regression (logit) analysis was performed in respect of all factors to verify whether all factors as a group are significant for early systemic risk (see Table 2 ). The obtained results show that the model is statistically reliable, because the "Prob $>$ chi2" criterion of the model is equal to zero, and the Pseudo R2 index shows that the model explains $76 \%$ of the fluctuations of the dependent variable. 


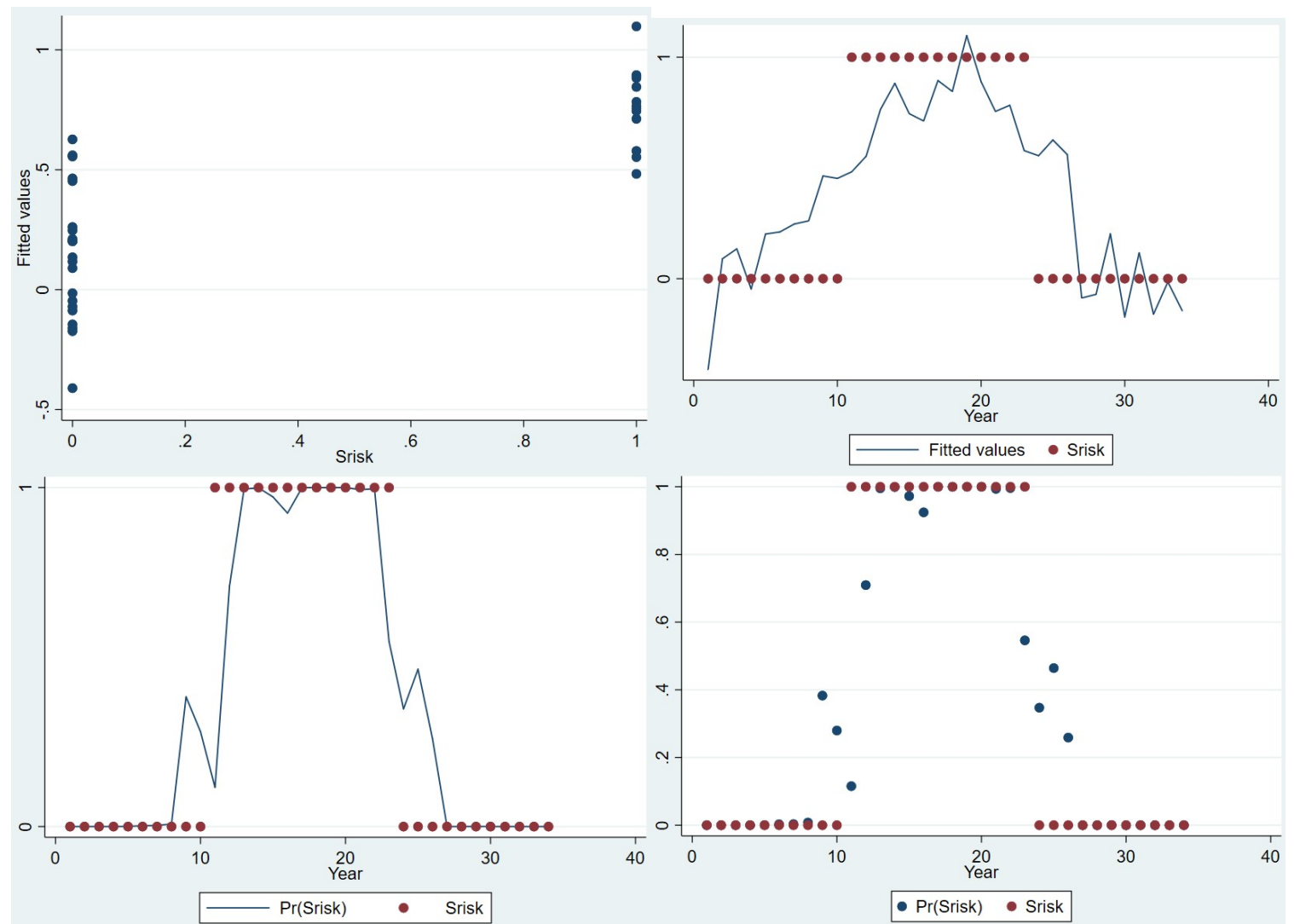

Figure 2. Estimates of dependent variable (linear regression calculated values, compared to actual values - on the top left, linear regression calculated and actual values in terms of time - on the top right, logistic regression calculated and actual values in terms of time - at the bottom left and right) Source: created by the author, using "Stata" software

Comparing the early model with the base model [13], it should be noted that the early systemic risk model is statistically more reliable. In the base model, the Stata statistical program was not able to calculate most of the statistical parameters of the model, while in the early model, all statistical parameters were calculated. The obtained results suggest that the data of financial derivatives can be used as an early indicator for an impending systemic crisis, and the model is suitable for an early warning system. During the next step, financial derivatives factors were analysed individually and the individual impact to early systemic risk of each of them was estimated. The analysis was performed using logistic regression analysis in respect of each financial derivatives factor, and a goodness of fit and classification tests were performed. The analysis shows that the best early indicators of impending systemic risk are those of size and leverage, which both explain a large part of the model (high Pseudo R2) and their results of goodness of fit test is high.
Table 2. Results of the logistic regression for financial derivatives factors in early systemic risk model

\begin{tabular}{|c|c|c|c|c|c|c|}
\hline \multirow{2}{*}{\multicolumn{3}{|c|}{ Logistic regression }} & & \multicolumn{3}{|c|}{ Number of obs } \\
\hline & & & & \multicolumn{3}{|c|}{ LR chi2(6) } \\
\hline & & & & \multicolumn{3}{|c|}{ Prob > chi 2} \\
\hline \multicolumn{3}{|c|}{ Log likelihood $=-5.4054082$} & & \multicolumn{3}{|c|}{ Pseudo R2 } \\
\hline $\mathrm{S}$ risk & Coef. & Std. Err. & $\mathrm{z}$ & $P>|z|$ & \multicolumn{2}{|c|}{$\begin{array}{c}\text { [95\% Conf. } \\
\text { Interval] }\end{array}$} \\
\hline Interconnection & -8.39183 & 6.813257 & -1.23 & 0.218 & -21.74557 & 4.961908 \\
\hline Size & 129.7566 & 251.2217 & 0.52 & 0.606 & -362.6288 & 622.1421 \\
\hline Liquidity & 125.0269 & 131.3892 & 0.95 & 0.341 & -132.4912 & 382.5449 \\
\hline Complexity & -78.19792 & 57.38639 & -1.36 & 0.173 & -190.6732 & 34.27734 \\
\hline Stability & -3.265678 & 15.38154 & -0.21 & 0.832 & -33.41294 & 26.88158 \\
\hline Leverage & -2.919068 & 135.1392 & -0.02 & 0.983 & -267.787 & 261.9489 \\
\hline cons & 228.825 & 254.9251 & 0.90 & 0.369 & -270.819 & 728.4691 \\
\hline
\end{tabular}

Source: created by the authors

These two factors can signal an impending systemic crisis in as many as $85 \%$ of cases. Table 3 contains a summary of the analysis. 
Table 3. Statistical parameters of the logistic regression for the impact of individual financial derivatives factors to early systemic risk

\begin{tabular}{|l|l|l|l|l|l|l|}
\hline Parameter & $\begin{array}{l}\text { Interconnection } \\
\text { factor }\end{array}$ & Size factor & $\begin{array}{l}\text { Liquidity } \\
\text { factor }\end{array}$ & $\begin{array}{l}\text { Complexity } \\
\text { factor }\end{array}$ & $\begin{array}{l}\text { Stability } \\
\text { factor }\end{array}$ & $\begin{array}{l}\text { Leverage } \\
\text { factor }\end{array}$ \\
\hline Pseudo R2 & 0.0672 & 0.5178 & 0.0362 & 0.5308 & 0.1233 & 0.4131 \\
\hline Prob > chi2 & 0.0812 & 0.0000 & 0.2007 & 0.0000 & 0.0182 & 0.0000 \\
\hline $\begin{array}{l}\text { Classification } \\
\text { test }\end{array}$ & $67.65 \%$ & $85.29 \%$ & $67.65 \%$ & $82.35 \%$ & $73.53 \%$ & $85.29 \%$ \\
\hline $\begin{array}{l}\text { Goodness of } \\
\text { fit test } \\
\text { Prob > chi2 }\end{array}$ & 0.0116 & 0.5100 & 0.3929 & 0.2766 & 0.7963 & 0.0269 \\
\hline Coefficients & 3.771402 & 71.0414 & 27.48492 & -54.51564 & 12.17069 & 35.10479 \\
\hline Odds ratio & 365.959 & $1.00 \mathrm{e}+50$ & $1.90 \mathrm{e}+11$ & $8.98 \mathrm{e}-22$ & $6.16 \mathrm{e}+07$ & $1.27 \mathrm{e}+24$ \\
\hline P $>\mathrm{z} \mid$ & 0.099 & 0.001 & 0.216 & 0.013 & 0.034 & 0.006 \\
\hline
\end{tabular}

Source: created by the authors

The analysis shows that the three factors interconnection, liquidity and stability - have the lowest Pseudo $R 2$ value. The criterion "Prob> chi2" is not met by two factors interconnection and liquidity, i.e. $0.0812>0.05$ and $0.2251>0.05$, respectively, which means that the interconnection and liquidity factors are not suitable for assessing the impact of financial derivatives on early systemic risk of the Euro area. The "Prob $>$ chi2" for the stability factor model is lower than the significance level $\alpha=$ 0.05 , but higher than " 0 ", while for the size, complexity and leverage factors "Prob $>$ chi2" criterion is equal to " 0 ". Thus, an analysis of the logistic regression of individual factors suggests that the factors of size, complexity, and leverage may be the best predictors of an impending systemic crisis.

The p-value criterion for the interconnection, liquidity and stability factors is also higher than for the other factors, and the coefficients are the lowest (the closer to "0", the less significant the variables are). The p-value criterion of the interconnection and liquidity factor is also higher than the significance level $\alpha$ $=0.05$, which confirms the results of the "Prob> chi2" parameter and the fact that these indicators should not be included in the early systemic risk model. The classification test shows that the interconnection factor can correctly predict systemic risk in $68 \%$ of cases, the liquidity factor in $68 \%$ of cases, and the stability factor in $74 \%$ of cases, which is significantly less than for other remaining factors. Meanwhile, the size factor can correctly predict systemic risk in $85 \%$ of cases, the complexity factor in $82 \%$ of cases, and the leverage factor in $85 \%$ of cases. Obviously, the size, complexity, and leverage factors are the best predictors of early systemic risk.

The coefficient of the interconnection factor is the smallest in absolute value, therefore, it can be assumed that if the other factors remain unchanged, and the interconnection factor changes by "1" unit, the logarithm of the systemic risk odds ratio would increase by 3.77 units. Meanwhile, the coefficient of the size factor is the highest in absolute terms, which allows to state that if the other factors remain unchanged, and the size factor changes by "1" unit, the logarithm of the systemic risk odds ratio would increase by 71.04 units. Therefore, given the values of the coefficients, it can be reasonably argued that size, complexity and leverage factors are the most significant and appropriate early indicators for assessing the early systemic risk in the Euro area.

Among the size, complexity and leverage factors, the size factor has the largest impact on the early systemic risk of the Euro area, since it's Pseudo R2 rating, the classification test and the coefficient is the highest. Although lower, however, the complexity factor also has a significant impact on systemic risk. It should be noted, that when comparing the results of the early systemic risk model with the base model [13], almost all statistical parameters of the interconnection, size, liquidity, stability and leverage indicators in the early model have worsened, while the statistical parameters of the complexity factor have improved. 
This situation suggests that, despite the importance of the size factor, the complexity factor is more appropriate as an early warning indicator, while other factors are more suitable for assessing the impact to the current period (non-early) systemic risk in the Euro area.

The results of the inter-correlation among the independent variables suggest, that the size and leverage factors are strongly correlated with each other (see Table 4). Their correlation is more than 0.9. Since these factors are strongly correlated with each other, it is best to include only one of these factors in the model. The correlation between the complexity and size factors is strong and between complexity and leverage is weak. The liquidity factor correlates very weakly with other factors. The correlation of the connection factor with size, complexity, and leverage factors is between weak -moderate and with other factors is weak. The correlation of the stability factor with size, complexity, and leverage factors is moderate and with other factors - weak. Summarizing inter-correlation between financial derivatives factors, it can be concluded that there is a significant correlation between statistically significant factors. This suggests that it is appropriate to eliminate some factors due to their inter-correlation.

Table 4. Inter-correlation among variables of early systemic risk model

\begin{tabular}{|c|c|c|c|c|c|c|c|}
\hline & $\begin{array}{c}\text { Early } \\
\text { systemic } \\
\text { risk }\end{array}$ & $\begin{array}{c}\text { Inter- } \\
\text { connection }\end{array}$ & Size & Liquidity & Complexity & Stability & Leverage \\
\hline $\begin{array}{c}\text { Early systemic } \\
\text { risk }\end{array}$ & 1 & & & & & & \\
\hline Interconnection & 0.2974 & 1 & & & & & \\
\hline Size & 0.6998 & 0.4637 & 1 & & & & \\
\hline Liquidity & 0.2182 & 0.0894 & 0.0495 & 1 & & & \\
\hline Complexity & 0.6929 & -0.4538 & -0.6217 & -0.2639 & 1 & & \\
\hline Stability & 0.3891 & 0.2798 & 0.5094 & 0.0940 & -0.5280 & 1 & \\
\hline Leverage & 0.5591 & 0.3184 & 0.9196 & -0.0626 & -0.3855 & 0.4378 & 1 \\
\hline
\end{tabular}

Source: created by the authors

Summarizing the carried-out regression analyses and other tests, it can be concluded that three factors of financial derivatives have a significant impact on the early systemic risk in Euro area: size, complexity, and leverage. However, only one of the sizes and leverage factors should be included in the model, as these factors highly correlate with each other.

During the last step it was assessed, whether all the factors of financial derivatives can be used in the early systemic risk model. The analysis is carried out in the linear regression model, since this model allows to identify and eliminate some model issues (for instance, multicollinearity, heteroskedasticity) more effectively. Also, is should be mentioned, that statistical software "Stata" doesn't allow to test for multicollinearity and heteroskedasticity issues in logistic regression. However, it is sufficient to test for these issues in linear regression, since multicollinearity and heteroskedasticity are characteristics, which exist among independent variables, despite the model used (linear, logistic or other).

First, the complete model is verified by performing a heteroskedasticity test. When testing the complete model, results show that no heteroskedasticity is detected in the model, i.e. the null hypothesis of homoskedasticity of the data is not ruled out, as "Prob> chi2" $=0.3711$, which is more than the significance criterion $\alpha=$ 0.05 (see Table 5).

Table 5. Results of the multicollinearity and heteroskedasticity tests in early systemic risk model

\begin{tabular}{|c|c|c|c|}
\hline & $\begin{array}{c}\text { Full linear regression } \\
\text { model }\end{array}$ & $\begin{array}{c}\text { Narrow linear regression } \\
\text { model (complexity) }\end{array}$ & $\begin{array}{c}\text { Narrow logistic regression } \\
\text { model (complexity) }\end{array}$ \\
\hline $\mathrm{R}^{2}$ & 0.6243 & 0.4801 & Pseudo R2 $=0.5308$ \\
\hline Heteroskedasticity test & $\begin{array}{c}\text { Chi2 }=0.80 \\
\text { Prob }>\text { chi2 }=0.3711\end{array}$ & $\begin{array}{c}\text { Chi2 }=0.71 \\
\text { Prob }>\text { chi2 }=0.3984\end{array}$ & - \\
\hline $\begin{array}{c}\text { Factors, that do not } \\
\text { satisfy p-value criteria }\end{array}$ & $\begin{array}{c}\text { Interconnection, size, } \\
\text { liquidity, stability, leverage }\end{array}$ & - & - \\
\hline $\begin{array}{c}\text { Multicollinearity (VIF } \\
\text { indicator) test }\end{array}$ & $\begin{array}{c}\text { Size }=14.19, \text { leverage }= \\
10.23, \text { complexity }=2.57\end{array}$ & - & - \\
\hline
\end{tabular}

Source: created by the authors 
To assess the multicollinearity, the VIF indicator was calculated. Results indicate, that VIF indicator is the highest for size (14.19) and leverage (10.23) factors, therefore, their elimination from the model is necessary. Analysis of p-value criterion for independent variables indicates, that among all the factors, the $p$-value criterion of the complexity factor is the lowest and satisfies the selected significance criterion, while other factors do not satisfy this criterion. Results allow to conclude that complexity factor is the only factor that can be used in the early systemic risk model.

Additionally, the model is verified by eliminating factors that do not meet required criteria, which means that the model is tested only for the single factor - complexity. Results of single (complexity) factor demonstrate that $\mathrm{R}^{2}$ of the model is equal to 0.4801 , i.e. the model explains $48 \%$ of the fluctuations of the dependent variable. Logistic regression analysis was performed for the identified one-factor (complexity) model. The Pseudo R2 parameter for the model is 0.5308 , and the instances of successful classification are $82 \%$. The $p$-value of the factor is 0.013 and the coefficient is equal to -54.51564 . Therefore, it can reasonably be argued that the complexity factor is an appropriate and sufficient factor for assessing the impact of financial derivatives on early systemic risk.
Conclusions. Conclusions of the given research and perspectives for further researches in the given direction. Summarizing the results, it can be noted that three factors - size, complexity and leverage - of financial derivatives can signal in advance about the impending systemic crisis. The size factor has the biggest impact on the probability of an impending systemic crisis. Nevertheless, complexity factor of financial derivatives is the only statistically significant factor that has an impact on early systemic risk. The results suggest that the inclusion of these factors in the systemic risk assessment models, which are developed by researchers, could increase the accuracy of the models.

The early systemic risk model is more reliable than the base model [13], which suggests that the data of financial derivatives can be used in early warning system models.

It should also be noted that the study reveals that financial derivatives have impact on early systemic risk, which can be identified through the highlighted factors. However, the systemic risk may not necessarily arise in financial derivatives, because there are many different financial products in the financial system. As a result, other financial instruments could also be the subject to further research by scientists. The inclusion of factors of various financial instruments could help to better identify the risks of the impending systemic crisis in systemic risk assessment models. 


\section{REFERENCES}

1. Macdonald, R., Sogiakas, V., \& Tsopanakis, A. (2015). An investigation of systemic stress and interdependencies within the Eurozone and Euro Area countries. Economic Modelling, 48, 5269. doi: 10.1016/j.econmod.2014.10.023

2. Duggar, E., \& Mitra, S. (2009). External linkages and contagion risk in Irish banks. IMF Staff Papers, 56(4), 758-786. doi: 10.1057/imfsp.2008.38

3. Caggiano, G., Calice, P., Leonida, L., \& Kapetanios, G. (2016). Comparing logit-based early warning systems: Does the duration of systemic banking crises matter? Journal of Empirical Finance, 37, 104-116. doi: 10.1016/j.jempfin.2016.01.005

4. Abino, D. J., Adrias, R. A., Damot, J. J., \& Virtucio, Z. M. (2014). Philippine Financial System Macrofinancial Vulnerabilities: Assessing and Forecasting Systemic Risk using LOGIT and VAR. Technical Session on Entrepreneurship, Business \& Management (II), 1-8. Retrieved from: https://www.dlsu.edu.ph

5. Cimpoeru, S. (2015). A logistic model on panel data for systemic risk assessment-evidence from advanced and developing economies. Journal of Applied Quantitative Methods, 10(1). Retrieved from: http://www.jaqm.ro

6. Powell, S.G., \& Barker, K.R. (2008). Classification and Prediction Methods. In S.G. Powell \& K.R. Barker. Management Science: The Art Of Modeling With Spreadsheets (p. 117-122). Hoboken, NJ: John Wiley \& Sons.

7. Rodríguez-Moreno, M., \& Peña, J. I. (2011). Systemic risk measures: the simpler the better? In D. Choi, Monetary Policy Committee Member \& Bank of Korea \& Bank for International Settlements, Systemic risk: Vol.60. Macroprudential Regulation and Policy (p. 29-35).

8. Mačerinskienè, I., Grigonis, V. (2015). Factors of financial instruments for systemic risk evaluation. XII International Scientific Conference "Management and engineering '15": conference proceedings. Sozopol: Technical University-Sofia, p. 917-926.

9. Mačerinskienè, I., Grigonis, V. (2019). Methodology and statistical analysis of the evaluation of the impact of derivatives on the country's systemic risk. Whither our economies 2019: 6th international scientific conference: conference proceedings. Vilnius: Mykolas Romeris University.

10. Laeven, M. L., \& Valencia, M. F. (2018). Systemic banking crises revisited. International Monetary Fund. Retrieved from: https://s3.eu-central-1.amazonaws.com

11. Lo Duca, M., \& Peltonen, T. (2011). Macro-financial vulnerabilities and future financial stress: Assessing systemic risks and predicting systemic events. IDEAS Working Paper Series from RePEc. Retrieved from: https://www.ecb.europa.eu

12. Evans, J. D. (1996). Straightforward statistics for the behavioral sciences. Pacific Grove, CA: Thomson Brooks/Cole Publishing Co.

13. Mačerinskienè, I., Grigonis, V. (2020). Evaluation of Derivatives Impact To Systemic Risk of Euro Area. Globalization and Its Socio-Economic Consequences, 10.

14. European Central Bank (2020). Euro area statistics. Retrieved from: https://www.ecb.europa.eu/stats/html/index.en.html. 